\title{
Language Interferences in Social Media
}

\author{
Juanda \\ English Department \\ Universitas Komputer Indonesia \\ Bandung, Indonesia \\ juanda@email.unikom.ac.id
}

\begin{abstract}
The purpose of this study is to find out the form of Indonesian language interference to regional/local languages. This study discusses the Indonesian language interference to regional/local language. In general, interference studies always discuss local language interferences to Indonesian, but the specificity of this study examines the forms Indonesian language interferences to local language. The method used is the description method that describes the discovery of interference data from Indonesian into mother's language or local language. Based on data from the social media in WhatsApp of the paspal group (a WA social media group (a class 1992 alumni of SMPN 1 Pagelaran-Pandeglang-Banten) are found using words that are similar in Indonesian, causing occurring interference such as the word 'Thanksgiving', 'learning', 'success'. One of the causes is the similarity of the two languages. This evidence shows that the Indonesian language interferences sundanese.
\end{abstract}

Keywords-interferences, politeness, communicative

\section{INTRODUCTION}

This study discusses Indonesian interference with Sundanese. Interference is a language error caused by the ability to master two or more languages that influence each other, namely the influence of the grammatical unit of language that was previously mastered on the next mastered language[1]. This error can occur at the level of phonology, lexical, or sentence structure. In general, this interference research focuses more on the mother tongue which affects the second language.

Previous research related to the topic of interference was carried out by Hidayat, Mokhtar, Mulyani, Sitompul, Triyanto $[1,2,3,4,5]$. All of the studies examined the mother language interfering in Indonesian. Very rarely of researches discuss Indonesian language that interferences with mother/local languages. In general researchers conducted their analysis of the influence of mother tongue/local language on Indonesian, but, the researcher tries to conduct a new study of Indonesian language interference with mother/local languages.

The purpose of this study is to find grammatical forms that appear in the structure of language used by users of WhatsApp groups called paspal and the factors that cause interference to appear in the sentence structure or in speech. The method used to obtain the results of this study by using the description method is to describe the conditions that exist in the conversation in WhatsApp group by classifying language data that belongs to the category of interference.

\section{METHOD}

The main point, this study wants to obtain interference data that occurs in bilingual or multilingual speakers. There are two main things that will be studied, namely the grammatical forms that appear in the WhatsApp group user speech actions "Paspal". In addition, the resersher wanted to find the factors that caused the speech to appear in the conversation in the group.

The most suitable method for examining this case is to use the description method by describing the conditions that occur in the whatsup group's speech. The steps are done by researcher are the recording data, grouping data according to the type of interference, analyzing forms of interference and explaining the factors that cause interference. The source of the data used is the recording of written conversations that occurred from April to August 2018 in the Paspal Group (a WA social media group (a class 1992 alumni of SMPN 1 Pagelaran-Pandeglang-Banten).

\section{RESULTS AND DISCUSSION}

The results of the data found in this study that interferences will occur in bilingual or multilingual because two or more languages that are controlled by speakers have similarities. For example in the word 'worry', the two words have similar sounds in Indonesian and Sundanese, causing interference. This is in line with the theories [6,7] that bilingual or multilingual will provide a great opportunity for interference. In addition, educational factors will also affect the choice of words, one example of speakers who maintain certain vocabulary because of prestige and to show high prestige when using the vocabulary.

Another thing that the occur to interference is that migration and political factors will bring up choices of words that affect interference. As stated by the following experts.

The origin of the emergence of bilingualism is caused by several things including population movements, nationalism and education movements [8,9]. Population movement, for various reasons such as military invasion, economic needs, distribution of business, political temperature and marriage. The nationalism movement, the growing awareness of colonized people to achieve independence usually determines certain languages as unifying all ethnic groups in the nation concerned. Education, the higher the education and cultural insight, the more other language skills will increase.

Several factors of bilingualism, including two languages that developed in the border area, when there was a minority of concentrated languages, population in a diverse area, changes in regional progress, type of work, social class, age and gender, and high level of language contact. The impact of that bilingualism can cause interference $[10,11]$.

The other finding of interference can also be caused by factors such as lack of familiarity of certain word forms such as "sick". The word in Sundanese is 'udur', 'sick'. 'Sick' is more 
familiar when using the word 'sick' in the Indonesian vocabulary. In WhatsApp the choice of words used is the word "sick" in Indonesian because it is considered more familiar. The theory that supports this discovery as stated in the theory below.

Apart from Indonesian, interference can also occur borrowing from foreign languages as in this case found borrowing words which are borrowing from English. Data found in the use of the word 'now'. This is in line with the theory below.

Interference can occur by borrowing certain words from certain languages because in the language being used. It is difficult to find the equivalent form and even if there is communication is less familiar if we do not borrow certain words $[12,13]$. Examples of the use of the word 'I'. When the speaker uses the word 'I' in Sundanese, the word cannot be used arbitrarily because many of the synonyms and 'I' are synonymous and must be used at certain levels. Therefore there was code switching or borrowing for the word. This is in accordance with the following theory.

Interference is the interaction of two language communities through the use of language [14,15], such as borrowing elements of language and code switching when the two language communities come into contact. Interference is the use of one language elements into another language when speaking or writing. We can understand that interference can be two-way from the first language to the second language or vice versa. Interference is not only caused by the speech of someone who deviates from the first Language norm as a result of his introduction to the second language but also vice versa, namely the deviation from the target language being studied in the first language [16,17].

Interference occurs because of the practice of using two languages alternately by bilingual speakers. Deviations that arise due to the use of two or more languages that contact each other. Differentiates interferences into two: retroactive and proactive interference $[18,19]$. Retroactive interference is the effect on the learning process due to the material that has been studied, while proactive interference is the effect as a result of the effects of material deviations that have been studied in advance. A second language that is similar to mother tongue can create an opportunity for interference. Interference can include three aspects, namely (1) the use of elements that are namely (1) the use of elements that belong to a language when speaking or writing other languages; (2) the application of two systems simultaneously to a Language; or (3) the result is a deviation from the norms of each language that occurs in bilingual speech [20,21].

Another finding is that interference can be caused by speakers being less loyal to the first language. In this case data was found as the word 'night'. Speakers are less loyal in using the word 'nigt' in Sundanese because the frequency of daily use of the word 'night' in Indonesian is more often used than the word 'night' in Sundanese. The theory that supports this discovery is the factors that cause interference are the bilingualism of speakers of the language, the low loyalty of the speakers of the first language, the inadequacy of the mother/local language vocabulary. The low frequency of vocabulary usage, the need for synonyms, the prestige of the source language, and the habits of the mother tongue [22,23].
This type of interference is divided into interference in the phonology, grammar, syntax, and lexicon fields [24,25].

Language as a communication tool can be in oral or written form. Current communication is not limited to lettershaped communication for verbal but already in a relatively faster form through the use of WA. The use of language in a certain variety has different characteristics. In WA language, although this form of communication is written, there is no editing in communication or speech, as in the written language of other forms of communication. An example in writing a letter will be editing or editing in compiling the speech.

In the language in WA is seen that the dominance of spoken speech is written so that the appearance of errors in language or interference is so great that the opportunity occurs in each speech. The speech expressed in each communication is of course highly prioritizing familiarity and more communicative. So that, there is a possibility of violations in terms of language rules, one of which is interference. Interference does not only occur from the regional/local language to the second language or Indonesian language but also can occur otherwise that interference from the second language to the first language. Communication in WA media usually uses mother tongue/local language to feel more psychologically familiar with the second language. Like the Sundanese people tend to use Sundanese but in certain grammatical units or units use Indonesian so that Indonesian language interference to regional/local languages.

West Java or Banten society has many speakers who have two languages, namely Sundanese and Indonesian. Sundanese people for the mention of the people of West Java and Banten are generally bilingual. The Sundanese people have mastered Sundanese and Indonesian languages in a balanced manner so that the chances of interference are likely to occur.

Pandeglang community when using Sundanese is very much dominated by Indonesian language interference because there is a speech that may be more comfortable by switching code that causes interference. The code transfer can be in the form of certain pronouns or vocabulary, which if we use a word in Sundanese will feel stiff and strange because it may not be familiar with the grammatical form. On the other hand, Sundanese in Pandeglang is still far from Sundanese standards Here are the discoveries of interference: makanya/pengen/bikin/sendiri/ambil dulu/ disatuin/di atas/ngga/berarti/bikin/airkelapa/kalau sudah jelas/bawa /belajarnal syukur/di/atas/aku/dah terbagi tuk semuanya/gerhana /meninggal/ walau/yang sekarang/yang ini/yang ini/orang tuanya yg sakit/ ibunya bapaknya/besoknya/buat/ katanya/adal siapnya/tiap/ bergantung/ tiap taun tiap sasih/jangan coba/coba/kangen/lagi, malem/dah beres dikumur2/berapa kali sehari minum/sehari besoknya/sakit kepala/abis dikumur telan/ya/dalam pipi/aku tahu/iya/ini/semangat/mulai/yg naksir/minum/domisilina /pencerahannyal yang Kamari/cepet busuk/ hamper//tiap /khawatir /musim/iya ya/manfaat/dipinjaman/da kemarin/serius/agak lefek/disaringnyal kalau buat orang lain yg /gak punya diabetes/dan berhasil/siapa'/saya/ditambih/enak makan /sukal penyembuhan sebulan badan enak/mati/garagara/ada/banyak/dah adapun sakit cuma minum air putih hangat/iya/mbludak/diketepel/politik/berhasil/nggak/ 
berarti/ ketemu/iya/ sehari/bikin sendiri/kental/sehari pengen/orang-orang/terbanyak/ ketemu /bikin/terbanyak.In English: so / want / make / own / take first / unite / above / not / mean / make / water whatever / if it is clear / bring / learn / thanksgiving / in / above / I / have been divided into all / eclipse / die / even though / who / now / this / this / his / her parents / sick mother / father / tomorrow / made / said / there is / ready / every / depends / every year every sasih / don't try / try / miss / again, okay rinsed / how many times a day drink / the next day / headache / dry mouth / swallow / yes / in the cheek / I know / yes / this / spirit / start / crush /drink / domicile / enlightenment / yang Kamari / fast rotten / almost // each / worry / season / yes / yes / benefit / borrowed / da yesterday / serious / somewhat / effect / filtered / if for others who / do not have diabetes / and succeed / who $1 /$ me / added / delicious food / likes / healing a month the body is good / dead / because of / there is / is a lot / has been sick just drinking warm water / yes / mbludak / tapped / politics / succeeded / not / means / find / yes / day / make yourself / thick / day want / people / most / meet / make / most.

The other interference speech forms that appear in the communication of WhatsApp of Paspal groups that are found, it is caused the low loyalty using these words. Here are tangan, punya, mengingat kenangan, aza, yang bisa bantubantu, nian, deket, manfaatnya, bermasalah dengan, lom, bersabarlah, siapin, lowbet, seperti itu, lebih kangen, harus ketemu, begitulah kayaknya, berangkat, met, akhirat. hands, have, remember memories, only, who can help, very, close, benefit, have problems with, yet, be patient, be ready, lowbet, like that, more miss, have to meet, like that, go, met, afterlife.

The cause of interference is the bilingualism of the speakers, the low loyalty of the speakers of the first language, the inadequacy of the first language vocabulary, the low frequency of vocabulary use, the need for synonyms, the prestige of the source language, and the habits of the mother tongue [12].

Basically speakers who are involved in the Paspal group are included in bilingual means mastering more than one language, namely regional languages and Indonesian. This is evidenced by the communication used by using Sundanese. Mastery of Indonesian in general students at the junior high school are considered to have mastered Indonesian. The low factor of the loyalty of speakers The first language of the mother's language is less loyal and consistent as the use of the word 'have' in Sundanese can have synonyms the words' boga ', 'have', 'gaduh', 'have' and 'kagungan' 'have' these three words will be different when used by speakers. The next factor is inadequate first language vocabulary like the word 'lowbet'. The use of foreign terms is felt to be simpler than the use of synonymous words in the first/local language. In addition, there is prestige in terms of source language. Another factor is the habits of the mother tongue such as the use of words that are similar in mother tongue that causes speakers to consider the same form of speech in the second language as the pronunciation has similarities but the writing is different as the word 'manfaat' 'benefit'and 'akhirat', 'after life'.

\section{CONCLUSION}

Basically interference is an overlap or language error, but in a variety of non-formal interference can be used as a tool to eliminate awkwardness in communication. By mixing Indonesian into regional languages communication feels closer and not rigid. This is actually a phenomenon of oral language is difficult to avoid. Besides that, the standard of local language in certain dialects always has differences due to cultural factors or it can be caused by educational background as well.

The theory or opinion of linguistic experts on interference is in line with this finding that cases of interference can occur in the language community that controls more than two languages. Theories that state that the language mastered before will affect the subsequent language use. The results of this study do not disprove the existing theory but only strengthen the theory presented by several language experts.

The grammatical form found is similarity in two languages while the cause is the habit of using Indonesian grammatical unit forms which, if replaced using Sundanese, the vocabulary looks very formal and makes communication less familiar. the factors that cause interference include the loyalty of Sundanese language users. Besides that specific vocabulary is rarely used so that the word is less familiar, which in the end many words are borrowed from Indonesian or sometimes there are several words taken from English.

\section{ACKNOWLEDGMENT}

The present writer gratefully acknowledge the support and generosity Rector of UNIKOM, Dean of Literary Faculty, and Head of English Department; without whom the present study could not have been completed.

\section{REFERENCES}

[1] Hidayat,R, "Interferensi Bahasa Jawa ke dalam Bahasa Indonesia pada Keterampilan Berbicara Siswa SMAN 1 Pleret, Bantul”, Jurnal Ling Tera, Vol.2, No.2,pp.1-9, 2015

[2] Mokhtar, M, "Interferensi Morfologis Penutur Bahasa Bugis dalam Berbahasa Indonesia”, Jurnal Humaniora, Vol.XII,No.2,pp.219--224, 2000.

[3] Mulyani,W., "Interfernsi Leksikal Bentuk Dasar Bahasa Jawa Tuban dalam Bahasa Indonesia: Suatu Tinjauan Deskriptif', Jurnal Bastra, Vol.1, No.2,pp.133-140, 2014.

[4] Sitompul,S.J.,'Interferensi Bahasa Batak Mandailing pada Penggunaan Bahasa Indonesia dalam Interaksi Kelas VII Madrasah Tsanawiyah Swasta", Jurnal Edukasi Kultura. Vol.2, No.2, pp.99-114, 2015.

[5] Triyanto,H.,"Interfernsi Gramatikal Bahasa Jawa dalam Bahasa Indonesia pada Karangan Laporan Peserta Didik SMP', Jurnal Ling Tera, ol3,No.1,pp.1-14, 2016.

[6] Briere, Eugen John. 1968. Psycholinguistics Study of Phonological Interference. Paris: The Hague

[7] Cantone,K.F. 2007. Code-Switching in Bilingual Children. Dordrech: Springer

[8] Apple,Rene and Pieter Musyken. 1987. Language Contact and Bilingualism. London: Arnold.

[9] Baker, Colin. 2006. Foundations of Bilingual Educations and Bilingualism. USA: Longman.

[10] Siemun,P. 2008. Language Contact and Contact Language. Amsterdam: John Benjamin

[11] Weinreich, Uriel. 1968. Language in Contact: Findings and Problems. New York: The Hague.

[12] Mills,R.W. \& Jean. 1993. Bilingualism in Primary School. London: Routledge

[13] Richard, Jack. 1974. Error Analysis: Perspective on Second Language Acquisition. London: Longman Group Ltd.

[14] Dulay, Heidi. et.al. 1982. Language Two. USA.Oxford University Press.

[15] Haugen, Einer. Bilingualism in the America. Alabama: American Dialec Sosiety.

[16] Holems, Janet. 2001. An Introduction to Sociolinguistics. New York. Longman.

[17] Smith, Sharwood. 1994. Second Language Learning: Theoretical Foundations. London: Longman. 
[18] Norrish, J.1983. Language Learners and Their Errors. London: The Macmillan Press.

[19] Fishman,A. Joshua.1972. Reading in the Sociology of Language. Paris: Yeshiva.

[20] Hoffman, C. 1991. An Introduction to Bilingualism. New York: Longman,

[21] James, C. 1998. Error in Language Learning and Use. London: Longman.

[22] Corder, S.Pit. Error Analysis and Interlanguage. New York: Oxford University Press.

[23] Jonathan, Michael. 2003. Introduction of Sociolinguistics. New York: Longman

[24] Grosjean, Francois. 1982. Life with Two Language Teaching. London: Longman Group Ltd.

[25] Scholes, R. \& Nancy R.C. 1982. The Practice of Writing. New York: ST. Martin's Press. 